\title{
Dilema Tata Kelola Pengungsi Global: Penanganan Illegal Maritime Arrivals (IMA) di Australia
}

\author{
Skolastika Genapang Maing \\ Magister Ilmu Hubungan Internasional, Universitas Muhammadiyah Yogyakarta - Indonesia \\ Email : nona.ibu21@gmail.com \\ Submitted: 6 Juli 2020 | Accepted: 25 Desember 2020
}

\begin{abstract}
Australia as one of the countries that signed the Convention of Refugee 1951 has an obligation to apply principle of non-refoulement in the handling of refugees and asylum seekers entering its territory. However, the issue of national security and domestic turmoil caused Australia to continue use restrictive policies in dealing with refugees and asylum seekers, especially those who came by the sea (boat people) and did not have official documents. They are called Illegal Maritime Arrivals (IMA). Giving the term "illegal" causes no distinction between IMA and smuggling/trafficking criminals. This paper aims to explain the existence of dilemma in the management of refugees especially in Australia in handling IMA. This research uses qualitative methods with secondary data sources from books, journals, articles and other sources related to the problem being studied. By using the concept of securitization approach in the paradigm of constructivism, this paper argue that the restrictive policies adopted by Australia as a form of protection of national interests. Australia experiences a dilemma in applying the principle of non-refoulement and protecting its national interests. This is challenge in the management of global refugees.
\end{abstract}

Keywords: Illegal, Maritime, Australia, Refugees.

\begin{abstract}
Abstrak
Australia sebagai salah satu negara yang menandatangani Konvensi Pengungsi 1951 mempunyai kewajiban untuk menerapkan prinsip non-refoulement dalam penanganan pengungsi dan pencari suaka yang memasuki wilayahnya. Namun di sisi lain, isu keamanan nasional dan gejolak dalam negerinya menyebabkan Australia tetap menggunakan kebijakan yang restriktif dalam menangani pengungsi dan pencari suaka khususnya yang datang melalui jalur laut (boat people) dan tidak memiliki dokumen resmi. Mereka disebut dengan Illegal Maritime Arrivals (IMA). Pemberian istilah "illegal" menyebabkan tidak ada pembedaan IMA dan pelaku kriminal smuggling/trafficking. Tulisan ini bertujuan menjelaskan adanya dilema dalam tata kelola pengungsi khususnya yang terjadi di Australia dalam penanganan IMA. Penelitian menggunakan metode kualitatif dengan sumber data sekunder yang berasal dari buku, jurnal, artikel maupun sumber lainnya yang berkaitan dengan masalah yang dikaji. Dengan menggunakan menggunakan pendekatan konsep sekuritisasi dalam paradigma kontruktivisme tulisan ini berpendapat bahwa kebijakan restriktif yang diambil oleh Australia sebagai bentuk perlindungan terhadap kepentingan nasionalnya. Australia mengalami dilema dalam menerapkan prinsip non-refoulement dan menjaga kepentingan nasionalnya. Hal ini menjadi tantangan dalam tata kelola pengungsi global.
\end{abstract}

Kata kunci: Illegal, Maritime, Australia, Pengungsi

\section{PENDAHULUAN}

Konvensi 1951 dan Protokol

1967 yang berkaitan dengan Status

Pengungsi merupakan kerangka normatif yang mengidentifikasikan sejumlah kewajiban khusus bagi negara-negara yang meratifikasinya. 
Dalam konvensi ini memuat prinsip non-refoulement yang penting dalam menetapkan bahwa seorang pengungsi tidak akan dikembalikan ke negara mana pun, dimana ia beresiko menghadapi penganiayaan. Konvensi Pengungsi 1951 memberikan perlindungan dan kesempatan bagi pengungsi untuk mendapatkan hakhaknya di negara suaka. Terdapat 145 negara yang meratifikasi konvensi tersebut dan beberapa diantaranya adalah negara yang menjadi tujuan pengungsi dan pencari suaka di dunia. Salah satu negara yang dimaksud adalah Australia.

Australia merupakan negara tujuan suaka bagi para pengungsi serta pencari suaka dari Asia dan Afrika. Kedatangan mereka ke Australia melalui dua jalur, yaitu jalur udara dengan menggunakan pesawat dan jalur laut dengan menggunakan perahu atau kapal laut. Para imigran yang menggunakan kapal laut disebut dengan boatpeople atau manusia perahu. Pada umumnya boat people merujuk pada para pencari suaka yang berusaha memperoleh suaka di Australia yang tidak dilengkapi dengan dokumen resmi. Mayoritas dari mereka berasal dari negara yang sedang mengalami konflik seperti Afghanistan, Iraq, Iran dan Sri Lanka. Sebelum tahun 2013, Australia menyebut boat people dengan Irregular Maritime Arrivals (IMA).
Terjadi peningkatan kedatangan boat people pada periode 2009-2013 dari 2.726 menjadi 20.587 jiwa atau meningkat $65 \%$ sesuai data yang dicatat oleh Parliemanet Library Australia (Phillips, 2014). Banyak pihak yang menganggap peningkatan jumlah pengungsi dan pencari suaka ini tidak hanya akan mengancam kedaulatan Australia, tetapi juga mengancam nilai sosial dan budaya, serta ancaman terorisme hingga ancaman terhadap nilai serta identitas lokal warga Australia (McDonald, 2005). Akibatnya Australia mengubah istilah "irregular" menjadi "illegal". Perubahan istilah ini berdampak pada penanganan IMA yang tidak berbeda dengan pelaku kriminal terkait smuggling dan trafficking.

Di sisi lain Australia dihadapkan pada kewajibannya memberi perlindungan internasional bagi para pengungsi dan pencari suaka terkait penerapan prinsip non refoulement. Australia dituntut memberi respon terhadap pergerakan pengungsi dan pencari suaka dengan simpati dan membuka perbatasannya. Selain merupakan tanggung jawab Australia secara internasional, pengungsi dan pencari suaka yang memiliki produktivitas tinggi diharapkan dapat memberi kontribusi serta dampak positif terhadap pembangunan ekonomi Australia. Selain itu, Australia juga memiliki kewajiban dalam hal 
penyediaan anggaran khusus terkait penanganan pengungsi dan pencari suaka. Australia berkewajiban terkait pemberian uang saku yang digunakan untuk tunjangan dan sewa akomodasi bagi para pengungsi yang datang ke negaranya (Phillips \& Spinks, 2013).

Namun setelah tahun 2001, Australia mulai mengadopsi kebijakan yang restriktif dan terbatas terkait penanganan IMA. Australia mulai menerapkan aksi perlindungan perbatasan dalam rangka mencegah penyelundupan manusia sebagai respon atas lonjakan arus kedatangan IMA. Dilema tata kelola terkait pengungsi dan pencari suaka mulai terlihat dimana negara suaka ditantang menjaga kepentingan nasionalnya dengan tetap menerapkan prinsip nonrefoulement terkait penanganan pengungsi dan pencari suaka.

Dalam penelitian terdahulu, sudah banyak yang menulis terkait dengan kebijakan penanganan pengungsi di Asutralia. Penelitian tahun 2015 oleh Rahmad Akbar yang berjudul "Dampak Kebijakan Australia terkait Isu Pencari Suaka terbadap Hubungan Bilateral Australia-Indonesia (2013-2015)" menjelaskan terkait hubungan Indonesia dan Australia yang terganggu sejak diperlakukannya Operation Sovereign Border. Indonesia merasa dirugikan dan telah berulang kali menyampaikan keberatannya terhadap kebijakan penanganan pencari suaka tersebut. Kebijakan ini dirasa lebih mementingkan kepentingan Australia dan mengabaikan kepentingan nasional Indonesia. Indonesia berharap Australia menghentikan kebijakan ini dan meneyelesaikan masalah ini pada Bali Process (Akbar, 2015). Selain itu jurnal yang ditulis oleh Fakhrul Rizal Razak (2018) yang berjudul "Kebijakan Unilateral Penanganan Imigran Ilegal Australia Pasca Pemiliban Umum Australia Tabun 2013". Penelitian ini menganalisis terkait keputusan menggunakan kebijakan militer untuk penanganan isu imigran illegal di Australia paca pemilihan umum tahun 2013. Temuan dari penelitian ini menunjukkan bahwa sekuritisasi yang dilakukan sejak masa kampanye hingga masa pemerintahan Perdana Menteri Tony Abbot adalah untuk mengangkat isu imigran illegal di Australia dalam agenda keamanan nasional Australia. Hal ini terkait kedaruratan isu imigran illegal yang menjadi ancaman bagi Australia. pendekatan strands of securitization digunakan untuk menjelaskan segala tujuan yang ingin dicapai aktor sekuritisasi terkait isu imigran illegal (Rizal, 2019). Dengan tema yang sama terkait sekuritisasi migrasi Australia, Dinda Ayu Saraswati (2019) dalam jurnalnya yang berjudul "Sekuritisasi Migrasi Australia pada masa Kepemimpinan Perdana Menteri Malcom Turnbull' berpendapat bahwa dengan 
menggunakan konsep sekuritisasi dapat menjelaskan upaya pemerintah Australia dalam mengartikulasikan isu migrasi sebagai ancaman. Upaya speech act yang dilakukan oleh Perdana Menteri Malcolm Turnbull begitu mempertimbangkan keseimbangan antara perlindungan perbatasan dan pemenuhan kewajiban internasional, mengingat terdapat krisis pengungsi yang terjadi tepat sebelum masa pemerintahannya dimulai (Saraswati, 2019).

Disisi lain Ni Luh Made Aprilia Marisa (2018) dalam tulisannya yang berjudul "Dilema Pemerintah Australia dalam Implementasi Prinsip Good International Citizenship pada Kebijakan terkait Pengungsi dan Pencari Suaka Pada Masa Pemerintahan Tony Abbott dan Malcolm Turnbull' menjelaskan bahwa dilema kebijakan Australia terjadi pada aspek ideasional, dimana prinsip good international citizen cenderung dekat dengan Partai Buruh sedangkan Partai Liberal memiliki cara berbeda dalam memahaminya. Dilema berpengaruh terhadap kebijakan Pemerintah Australia terkait pengungsi dan pencari suaka. Australia alih-alih mengubah kebijakannya sesuai dengan opini publik, malah melakukan issue framing (Marisa, 2018). Penelitian lain yang juga meneliti kebijakan Australia terkait penanganan pengungsi pada masa pemerintahan Tony Abbott adalah tulisan Nadrah Ulfah (2019) yang berjudul "Perlindungan Keamanan Manusia Australia melalui Kebijakan Turn Back The Boat pada Masa Pemerintaban Tony Abbote' yang menjelaskan terkait penyebab Australia menerapkan kebijakan Turn Back the Boat dalam penanganan pengungsi dan pencari suaka. Menggunakan konsep buman security, penulis menjelaskan alasan Australia mengeluarkan kebijakan tersebut karena keamanan manusia Auatralia terancam akibat datangnya pengungsi dan pencari suaka terutama dalam aspek keamanan lingkungan dan keamanan pribadi (Ulfah, 2019).

Berdasarkan beberapa studi terdahulu di atas, diketahui bahwa sudah banyak penelitian terkait penanganan IMA, tetapi yang berbeda dengan penulisan ini adalah penelitian lebih sepesifik menganalisa adanya dilema tata kelola global terkait pengungsi dan pencari suaka, khususnya penanganan isu IMA di Australia. Fenomena kebijakan sekuritisasi Australia dalam menangani IMA dapat dilihat sebagai "dilema" yang terjadi terkait penanganan pengungsi dan pencari suaka. Australia merupakan salah satu negara yang meratifikasi Konvensi 1951 sehingga mempunyai tanggung jawab menerima pengungsi dan pencari suaka yang masuk ke wilayahnya. Namun dalam penanganan IMA, Australia mulai menerapkan kebijakan yang dianggap bertentangan dengan konvensi 
pengungsi tersebut. Hal ini dapat menjadi tantangan dalam tata kelola global terkait isu pengungsi dan pencari suaka. Selain itu, penelitian ini juga menggunakan menggunakan konsep sekuritisasi dalam paradigma kontruktivisme untuk menjelaskan tindakan Australia tersebut.

\section{METODE PENELITIAN}

Tulisan ini menggunakan metode kualitatif dengan sumber data sekunder yang berasal dari buku-buku, jurnal, laporan, sumber daring dan liputan dari majalah ataupun koran yang terkait dengan tema yang dibahas. Sumber-sumber tersebut diolah dan dipilih secara selektif sehingga data yang diperoleh dapat dipercaya.

Hasil dari penelitian ini akan dibahas dalam 4 (empat) bagian yaitu bagian pertama menjelaskan terkait tata kelola global dan penerapan prinsip non-refoulement sebagai pengantar dalam memahami tata kelola pengungsi dan pencari suaka secara global; bagian kedua menjelaskan terkait kebijakan Australia dalam penanganan IMA; bagian ketiga menjelaskan kerjasama dengan negaranegara transit pengungsi dan pencari suaka terkait dengan penanganan IMA sebagai salah satu unsur dalam tata kelola global; dan bagian terakhir akan membahas kritik internasional terhadap kebijakan Australia dalam penanganan isu IMA khususnya terkait tempat penahanan pengungsi di Pulau Manus dan Nauru.

\section{PEMBAHASAN}

\section{Tata Kelola Global terkait Pengungsi dan Penerapan Prinsip Non-Refoulement}

Pengungsi internasional telah menjadi masalah global diakibatkan adanya konstelasi politik yang menimbulkan konflik di berbagai belahan dunia dan memaksa orang untuk meninggalkan negaranya. Mereka terpaksa melintasi perbatasan untuk mencari perlindungan terhadap keselamatannya di negara lain. Dalam tata kelola hubungan internasional, terdapat sejumlah aturan yang mempunyai posisi sebagai nilai-nilai universal yang berfungsi mengatur sistem hidup secara global. Oleh karena itu, pengungsi menjadi isu yang perlu mendapat perhatian dalam tata kelola hubungan internasional. Pengungsi menjadi bukti bahwa sistem suatu negara tidak dapat menjamin keteraturan dan keadilan internasional. Dengan demikian, kehadiran pengungsi dilihat sebagai suatu peluang dalam menciptakan keteraturan dunia sehingga wajar apabila negara-negara mulai bekerjasama dan membentuk organisasi yang menjadi rezim internasional terkait pengungsi.

Suatu rezim internasional untuk mendefinisikan dan menyediakan 
perlindungan hukum bagi para pengungsi mulai muncul setelah terjadinya Perang Dunia I (PD I). Pada tahun 1921, Liga Bangsa-Bangsa (LBB) membentuk Kantor Komisaris Tinggi untuk Pengungsi yang merupakan sebuah institusi/lembaga yang mempunyai ruang lingkup geografis yang sifatnya terbatas sehingga tidak efektif dan bertahan lama.

Dalam mengatasi perpindahan besar-besaran selama PD II, sekutu membentuk United Nations Relief and Rehabilitation Agency (UNRRA) pada tahun 1943. UNRRA memiliki mandat yang sangat sempit, karena hanya terbatas untuk mengawasi pemulangan orang-orang yang terlantar di Eropa. Akhirnya UNRRA dihapuskan dan diganti dengan International Refugees Organization (IRO) pada tahun 1947. IRO memiliki mandat yang lebih komprehensif tetapi juga berfokus pada penyelesaian perpindahan akibat perang. Secara pararel, pada tahun 1948 sebuah badan PBB didirikan untuk menyediakan program bantuan dan pekerjaan bagi para pengungsi di Palestina. Badan PBB tersebut dinamakan United Nations Relief and Works Agency (UNRWA) yang mulai beroperasi pada tahun 1950. Akibat lonjakan arus pengungsi baru sebagai konsekuensi dari partisi India, serta peristiwa di Korea dan China, maka dibentuk Kantor Badan PBB yaitu
United Nations High Commisioner of Refugees atau UNHCR pada tahun 1951. Pada awal pembentukannya, UNHCR adalah sebuah agensi dengan 7.500 staf yang mewakili lebih dari 120 negara dan mengelola anggaran sebesar \$3,5 miliar (Khoser, 2014). Organisasi ini termasuk organisasi yang terkemuka di dunia yang bertugas mengurus pengungsi secara global.

Landasan yang menjadi kerangka hukum dan dasar untuk tugas dan fungsi dari UNHCR adalah Konvensi 1951 dan Protokol 1967. Kerangka hukum ini mengatur Status Pengungsi. Dalam Konvensi 1951, pengungsi diartikan sebagai orang yang "karena ketakutan yang beralasan dianiaya karena alasan ras, agama dan kebangsaannya, dan tidak dapat untuk atau karena ketakutan semacam itu, tidak bersedia untuk memanfaatkan perlindungan negara itu sendiri" (UNHCR, 1951). Definisi ini tidak berfokus pada orang-orang yang terlantar lintas batas dan tidak termasuk dengan Internally Displaced Persons (IDP's) yang terjadi di seluruh dunia saat ini.

Selain mendeskripsikan terkait dengan definisi pengungsi, kerangka hukum ini juga memberikan kerangka kerja normatif dengan mengidentifikasi sejumlah kewajiban khusus bagi negara-negara pihak dan mandat yang meluas bagi UNHCR untuk merumuskan solusi permanen 
bagi pengungsi dan pencari suaka. Tiga solusi permanen yang dimaksud yaitu pertama, pemulangan sukarela (repatriation) yang menggambarkan kembalinya pengungsi ke negara asal pengungsiannya dengan aman; kedua, integrasi lokal (local integration) yaitu penyelesaian permanen bagi para pengungsi di negara suaka; dan ketiga adalah pemukiman kembali (resettlement) dimana solusi ini menggambarkan suatu proses pemindahan pengungsi dari negara suaka mmereka untuk dimukimkan secara permanen di negara lain. Negara- negara tempat resettlement pengungsi yang paling penting di dunia adalah Amerika Serikat, Kanada dan Australia. Selain solusi permanen tersebut hal yang paling penting dan diatur dalam konvensi ini adalah prinsip non-refoulement yang berlaku bagi negara-negara pihak.

Prinsip non-refoulement tersebut menetapkan negara pihak untuk tidak melakukan penolakan, pengembalian atau pengiriman pengungsi ke suatu tempat yang berbahaya dan mengancam hidupnya. Hal ini terkait pembunuhan, penganiayaan dan sebagainya, atau dapat pula disebabkan alasan yang berkaitan dengan suku, agama maupun kebangsaan, serta keanggotaanya dalam organisasi atau keyakinan politik tertentu. Tindakan menolak atau memaksa pengungsi kembali ke negara asalnya dianggap bertentangan dengan prinsip yang berlaku secara internasional tersebut. Tindakan ini mengingkari komitmen dari komunitas internasional untuk berkontribusi dalam penyelesaian masalah pengungsi yang dilakukan melalui penandatanganan Konvensi PBB tersebut (Nurcahyawan \& Andika, 2017).

Australia merupakan salah satu negara pihak yang menandatangani Konvensi 1951. Australia juga menerapkan prinsip Good International Citizenship (GIC) dalam implementasi kebijakan luar negerinya. Prinsip ini sebagai turunan dari pandangan kaum idealis terkait tatanan dunia yang harmonis (Evans, 2004). Pada umunya prinsip GIC sejalan dengan prinsip non-refoulement yang menjadi dasar memperlakukan pengungsi yang masuk ke negaranya. Oleh sebab itu, Australia diwajibkan untuk bersikap simpati dan membuka wilayahnya untuk pengungsi dan pencari suaka. Namun implementasinya terlihat adanya penyimpangan dari prinsip tersebut. Adanya hambatan politik, teknis dan keuangan yang signifikan akibat lonjakan pengungsi menjadi alasan yang menyebabkan terjadinya penyimpangan. Hal ini menjadi tantangan serius bagi tata kelola global, dimana gejolak dalam negeri negara suaka menyebakan penerapan sekuritisasi terhadap pengungsi. 
Kebijakan Restriktif Australia dalam Penanganan Illegal Maritime Arrivals (IMA)

Pengungsi menjadi masalah serius yang dihadapi Australia dalam beberapa tahun terakhir ini. Terkait dengan penanganan pengungsi, Australia telah menghabiskan anggaran yang cukup besar untuk pengelolaannya. Dalam penelitian Rahmad Akbar (2015) mengemukakan bahwa antara tahun 2013-2014, anggaran yang dikeluarkan Australia untuk menangani lonjakan pengungsi dan pencari suaka mencapai sebesar \$10,3 miliar (Akbar, 2015). Hal ini sangat serius dan berpengaruh terhadap stabilitas ekonomi Australia. Banyak anggapan bahwa anggaran yang sebesar itu lebih bermanfaat jika dialokasikan untuk pembangunan infrastruktur atau biaya pendidikan bagi masyarakat Australia, dibandingkan dengan hanya mengurusi pengungsi dan pencari suaka. Namun apabila dilihat dari isiKonvensi Pengungsi 1951 yang diratifikasi Australia, pengeluaran anggaran yang dilakukan negara tersebut telah sesuai dengan tanggung jawabnya.

Tabel. 1 Jumlah Pengungsi dan Pencari Suaka di Australia 2013-2018

\begin{tabular}{ccc}
\hline Tahun & Pengungsi & Pencari Suaka \\
\hline 2013 & 34,503 & 10,999 \\
\hline 2014 & 35,582 & 8,211 \\
\hline 2015 & 36,917 & 11,549 \\
\hline 2016 & 15,553 & 12,673 \\
\hline 2017 & 20,257 & 18,267 \\
\hline 2018 & 62,732 & 27,884 \\
\hline TOTAL & $\mathbf{2 0 1 5 , 5 4 4}$ & $\mathbf{8 9 , 5 8 3}$ \\
\hline
\end{tabular}

Sumber: Data UNHCR yang diolah Penulis

Berdasarkan data Tabel 1 terlihat jelas adanya kenaikan yang signifikan terkait jumlah pencari suaka yang datang ke Australia. Pada umumnya para pencari suaka adalah yang datang melalui jalur laut (boat people) dan tanpa mempunyai dokumen yang resmi. Status mereka adalah illegal atau biasa disebut Illegal Maritime Arrivals (IMA).

Istilah "illegal" baru digunakan Australia pada awal tahun 2013, karena sebelumnya Australia menggunakan istilah "irregular". Perubahan istilah menjadi salah satu indikasi bahwa Australia mulai merasa terancam dengan adanya IMA tersebut. Pada Juni 2013, dilakukan amandemen terhadap The Migration Regulation 1994 yang menyatahkan bahwa segala kedatangan dari jalur laut yang dianggap tidak teratur (irregular) dan status hukum yang diperolehnya sama 
dengan orang yang masuk ke negara Australia melalui wilayah lepas pantai yang tidak termasuk zona migrasi (excised offshore place). Hal ini menunjukkan adanya dasar perlakuan yang berbeda oleh Pemerintah Australia terhadap para pelaku IMA. Mereka tidak diperlakukan berbeda dengan pelaku kriminal penyelundupan dan perdagangan manusia (smuggling/ trafficking) karena tidak ada pembeda yang jelas.

Jika dikaji lebih mendalam dari aspek historis, kebijakan yang bersifat terbatas dan restriktif terhadap IMA sudah dimulai sejak pemerintahan Perdana Menteri John Howard. Dalam Pemerintahan Howard, Australia menerapkan kebijakan Pacific Solution (Solusi Pasifik) dengan mmenerapkan berbagai strategi dengan tujuan mencegah dan menekan lonjakan kedatangan IMA. Solusi Pasifik dilaksanakan dengan penahanan kapal yang memuat para pencari suaka yang akan memasuki wilayah migrasi Australia, serta melakukan resettlement para pencari suaka yang mendapatkan status pengungsi. Hal ini menekankan pada tiga aspek penting yaitu pertama, Howard berusaha menghilangkan zona migrasi di Australia; kedua, kerjasama untuk membangun pusat penanganan IMA dengan negaranegara di Asia Pasifik khususnya Nauru dan Papua Nugini; dan ketiga, Howard berusaha membuat beberapa amandemen Undang-Undang Migrasi Australia untuk mengurangi hak-hak yang diterima oleh pengungsi (Alunaza, Maulana, \& Sudagung, 2018). Kebijakan Howard menjadi perintis dibukanya Offshore Processing Center atau tempat detensi pencari suaka di zona lepas pantai Australia dan di negara lain yang merupakan daerah perbatasan dengan Australia. Kebijakan ini dilengkapi dengan memberikan Temporary Protection Visa atau TPV bagi para pencari suaka yang sifatnya illegal dan akan ditetapkan sebagai pengungsi (McAdam \& Purcell, 2008).

Setelah John Howard, Pemerintah Australia dipimpin oleh Perdana Menteri yang berasal dari Partai Buruh yaitu Kevin Rudd (20072010) dan Julia Gillard (2010-2013). Pada umumnya kebijakan Partai Buruh mengedepankan aspek keadilan, integritas dan kemanusiaan sebagai respon terhadap isu pengungsi dan pencari suaka. Hal ini dapat dilihat dari upaya menghentikan kebijakan Pacific Solution, menghapus pemberian visa proteksi (TPV) dan diganti dengan visa permanen, serta memperkenalkan adanya kebijakan New Direction in Detension yang menjadi revisi dari kebijakan penahanan di Australia. Namun perubahan dari kebijakan yang dirumuskan oleh Perdana Menteri dari Partai Buruh ini malah mengakibatkan 
lonjakan jumlah pengungsi ke Australia.

Pada rentang waktu 2013-2015 terjadi pergantian Perdana Menteri oleh Kevin Rudd yang memimpin untuk periode kedua. Namun pemerintahan Kevin Rudd tidak berlangsung lama dan segera diganti oleh Perdana Menteri dari Partai Liberal yaitu Tony Abbott (2013-2015). Dengan latar belakang Partai Liberal yang menggunakan hard policy untuk menangani pengungsi dan pencari suaka, maka Tony Abbot masih mempertahankan kebijakan yang restriktif terkait IMA. Abbot mengembalikan visa proteksi dan penggunaan militer dalam penanganan IMA. Hal ini terlihat dari kebijakan Operation Sovereign Border yaitu dalam rangka menjaga kedaulatan wilayah perbatasan Australia dari ancaman IMA. Australia juga menerapkan kebijakan Turn Back the Boat dengan meminta kapal-kapal yang membawa pengungsi untuk keluar dari wilayah perairan Australia dan dikembalikan ke negara dimana tempat kapal tersebut berangkat. Kebijakan ini bersifat koersif, dimana Australia menolak siapa saja yang datang menggunakan perahu ke wilayahnya dan mereka tidak akan mendapatkan hak untuk menetap atau bermukim di Australia (Ulfah, 2019). Selain itu, Abbot kembali menggunakan kebijakan-kebijakan yang restriktif yang sebelumnya telah dijalankan oleh Australia. Dari rentang waktu 2010 sampai 2015, kebijakan Australia terhadap IMA terkesan menggunakan kebijakan yang dianggap bipartisan, tetapi berbeda terkait pendekatannya. Perbedaan pendekatan yang digunakan ini menunjukkan pragmatisme terkait usaha penyesuaian diri terhadap segala gejolak yang terjadi dalam politik domestik ditingkat masyarakat maupun pemerintah Australia. Abbot kemudian diganti oleh Malcolm Turnbull (2015-2018) yang juga berasal dari Partai Liberal sehingga masih menerapkan kebijakan yang sama. Kebijakan yang restriktif ini terus dipertahankan Australia hingga Perdana Menteri Scoot Morison (2018sekarang). Semua kebijakan Australia terkait penanganan IMA pada tahun 2013-2018 dapat dilihat pada tabel berikut: 
Tabel 2. Kebijakan-Kebijakan Perdana Menteri Australia terkait Penanganan IMA Tahun 2013-2018

\begin{tabular}{|c|c|c|}
\hline Perdana Menteri & Partai & Kebijakan \\
\hline \multirow{4}{*}{$\begin{array}{l}\text { Julia Gillard } \\
(2010-2013)\end{array}$} & \multirow{4}{*}{ Buruh } & - Menghentikan Pacific Solution \\
\hline & & $\begin{array}{l}\text { - Menghapus Visa Proteksi (TPV) dan diganti dengan } \\
\text { Visa Permanent }\end{array}$ \\
\hline & & - New Direction in Detension \\
\hline & & - Humanitarian Program \\
\hline $\begin{array}{l}\text { Kevin Rudd II } \\
(2013-2013)\end{array}$ & Buruh & $\begin{array}{l}\text { Periode I : Menggunakan kebijakan yang tidak berbeda } \\
\text { dengan Perdana Menteri Julia Gillard } \\
\text { Periode II : Menggunakan hard policy dengan membuka } \\
\text { Offshore Processing Center }\end{array}$ \\
\hline $\begin{array}{l}\text { Tony Abbott } \\
(2013-2015)\end{array}$ & Liberal & - Mengembalikan Visa Proteksi (TPV) \\
\hline $\begin{array}{l}\text { Malcolm Turnbull } \\
\quad(2015-2018)\end{array}$ & Liberal & $\begin{array}{l}\text { - Operation Sovereign Border (OSB) } \\
\text { - Burn Back the Boat }\end{array}$ \\
\hline $\begin{array}{l}\text { Scott Morrison } \\
\text { (2018-sekarang) }\end{array}$ & Liberal & $\begin{array}{l}\text { - Offshore Processing and Settlement } \\
\text { - Fast-Track Processing of Asylum Claims }\end{array}$ \\
\hline
\end{tabular}

Sumber: data diolah penulis

Dari penerapan kebijakan yang berbeda-beda terkait penanganan IMA, Australia berhadapan dengan dua kepentingan yaitu berusaha menjaga akomodasi aturan terkait Hak Asasi Manusia (HAM) internasional dan berusaha menghentikan arus pengungsi dan pencari suaka ke Australia. Langkah yang dianggap simbolik yaitu dengan mengubah istilah "irregular" menjadi "illegal" serta adanya pergantian Departement of Imigration and Citizenship menjadi Departement Imigration and Border Protection, menunjukkan dampak yang besar terkait tata kelola penanganan IMA. Perubahan istilah ini awalnya dikemukakan oleh Perdana Menteri Scoot Morison yang pada saat itu masih menjabat sebagai Menteri
Departement Imigration and Border Protection. Perubahan ini secara tidak langsung dapat mengambarkan rasa terancamnya akan kehadiran IMA yang rentan dengan masalah perdagangan dan penyelundupan manusia. Selain itu perubahan ini juga dapat menegaskan pencegahan masuknya IMA ke wilayah teritorial Australia serta menyiratkan adanya upaya untuk mengkriminalisasi IMA.

Definisi illegal dapat menjadi stigma yang menganggap IMA sama dengan pelaku kejahatan tanpa memandang motif dan keadaan dari pengungsi tersebut. Secara tidak langsung Australia memberikan penegasan bahwa negaranya tidak secara permanen melindungi IMA yang berasal dari negara lain yang 
berusaha mencari suaka di wilayahnya. Padahal kenyataannya pengungsi tersebut banyak mengalami situasi yang rentan dari negaranya dan mencari perlindungan terhadap ancaman hak-haknya. Menurut paradigma kontruktivis, perubahan istilah ini juga menjadi salah satu bentuk kontruksi sosial untuk mengubah padangan warga Australia terhadap IMA. IMA dipandang sebagai imigran illegal dan bagian dari suatu tindak kejahatan, sehingga tidak ada kemungkinan untuk IMA dipertimbangkan statusnya sebagai pengungsi.

Keputusan lain yang juga menunjukkan tindakan yang mengkriminalisasi IMA yaitu Operation Sovereign Border atau OSB. Operasi ini terkait kepentingan nasional Australia yaitu memprioritaskan keamanan nasional dalam menghadapi isu IMA. OSB adalah salah satu perubahan signifikan dari kebijakan yang diambil oleh Australia terkait penanganan pengungsi dan pencari suaka. Penerapan OSB dilihat sebagai penekanan krisis terkait perlindungan perbatasan dari ancaman IMA. Australia berada dalam situasi national emergency atau dengan kata lain, IMA sebagai musuh dan target operasi militer Australia (Cadwallader, 2015). IMA dipersepsikan menjadi ancaman bagi Australia. Melihat dari konteks sekuritisasi, Nadrah Ulfah (2019) mengemukakan bahwa ancaman ini dapat dilihat dari tujuh aspek keamanan manusia (Ulfah, 2019), yaitu (1) keamanan ekonomi dalam konteks keamanan individu dapat dikaitkan dengan pekerjaan dan pendapatan. Ancaman yang muncul dengan adanya pengungsi dan pencari suaka adalah semakin berkurangnya lapangan pekerjaan dan akses terhadap peluang ekonomi lainnya. Hal ini dapat menimbulkan kemiskinan dan pengangguran; (2) keamanan pangan terkait akses yang dapat menjamin seseorang memperoleh makanan yang aman dan tidak berbahaya dalam jumlah yang mencukupi, sehingga dapat berguna bagi pertumbuhan dan perkembangan mereka dengan tujuan hidup dengan sehat; (3) keamanan kesehatan terkait perlindungan terhadap berbagai pernyakit yang berpeluang ditularkan dari para pengungsi atau pencari suaka; (4) keamanan lingkungan yang merupakan perlindungan terhadap lingkungan dan kepentingan vital dari warga negara akibat dampak yang datang dari luar maupun dalam yang mengancam kekayaan hayati, fungsi ekosistem serta keberlangsungan kehidupan manusia. Populasi pengungsi dan pencari suaka yang makin meningkat dikhawatirkan dapat menambah tekanan terhadap lingkungan serta memberikan dampak ekologis dan peningkatan polusi; (5) keamanan individu terkait ancaman 
yang disebabkan individu dan bukan tindakan negara, seperti ancaman terorisme. Dimana mayoritas pengungsi dan pencari suaka yang adalah Muslim dilihat menjadi peluang masuknya teroris ke wilayahnya; (6) keamanan komunitas yaitu melindungi masyarakat atau kelompok tradisional tertentu dari hilangnya nilai-nilai budaya tertentu. Ada persepsi bahwa kedatangan pengungsi dan pencari suaka dapat mengancam nilai atau norma budaya Australia karena mereka tidak terintegrasi dengan kehidupan masyarakat Australia; dan (7) keamanan politik terkait represi politik, pelanggaran HAM dan kurangnya aturan hukum serta keadilan.

Dengan demikian kebijakan sekuritisasi migrasi Australia bukan semata-mata dilihat sebagai tindakan restriktif terhadap pengungsi dan pencari suaka, tetapi sebagai suatu pencerminan dari upaya menjaga kepentingan nasionalnya.

\section{Kerjasama Penanganan Illegal Maritime Arrivals (IMA)}

Dalam menangani isu IMA, Australia tidak mampu menjalankan kebijakannya sendiri tanpa upaya untuk mengambarkan dan melihat adanya pengaruh yang besar dari kehadiran negara-negara di sekitarnya, khusus negara-negara yang berbatasan langsung dengan wilayahnya. Negara- negara ini menjadi pintu masuk ke wilayah Australia dan merupakan tempat transit pengungsi dan pencari suaka. Negara-negara yang dimaksud adalah Indonesia, Malaysia dan negaranegara di Asia Pasifik. Australia mempunyai kepentingan untuk menjalin komunikasi yang baik dengan negara-negara Asia Pasifik karena adanya justifikasi untuk dapat mengangkat isu IMA tersebut ke tingkat regional. Kerjasama yang dilakukan Australia bertujuan memberikan pemahaman dan kepentingan yang sama dalam melihat urgensi isu IMA menjadi ancaman keamanan kedaulatan negara. IMA dianggap dapat menjadi jalur upaya penyelundupan manusia serta masuknya terorisme.

Sebagai awal, Australia merintis kerjasama dengan Indonesia. Indonesia adalah negara yang penting karena menjadi salah satu negara transit pengungsi dan pencari suaka yang berniat menuju Australia. Sejak tahun 1990-an, telah ada kerjasama bilateral dengan Indonesia dalam hal pemberian bantuan penguatan kapasitas bagi pengawasan perbatasan serta pembangunan infrastruktur penahanan bagi pencari suaka yang berada di Indonesia. Selain itu, Australia juga memberikan bantuan baik teknis maupun finansial untuk otoritas imigrasi di Indonesia melalui kerjasama Regional Cooperation 
Arrangement atau RCA. Kerjasama antara pemerintah Australia Indonesia dan International Organization for Migration (IOM) melalui RCA sudah dimulai pada tahun 2000. RCA memberi mandat kepada Indonesia agar berperan untuk menahan uapaya imigrasi ke wilayah Australia melalui jalur Selandia Baru yang tidak wajar sehingga diajukkan ke IOM untuk penanganan lebih lanjut (Millar, 2004).

Upaya lain yang juga dirintis oleh Australia adalah melalui Bali Process on People Smuggling, Trafficking in Persons and Related Transnational Crime (Bali Process) pada tahun 2002. Pertemuan ini dilatar belakangi oleh inisiasi atau dorongan dari negara-negara besar terutama Australia yang mengalami peningkatan arus penyelundupan manusia dari kawasan Afghanistan dan Iraq pada beberapa tahun terakhir. Kepentingan dari Australia tersebut kemudian dibicarakan dengan Indonesia dan coba diselaraskan bersama kepentingan dari negara-negara lain yang melihat masalah penyelundupan dan perdagangan manusia merupakan isu penting yang wajib dibicarakan secara bersama. Forum ini juga sebagai langkah awal Australia membawa isu pencari suaka ke tingkat regional melalui diplomasi. Diplomasi yang dilakukan ini dinilai sukses karena berhasil menyelenggarakan Bali Process yang fokus terhadap penyelesaian persoalan penyelundupan serta perdagangan orang dan kejahatan transnasional lainnya (Wuryandari, 2010). Selain itu keberhasilan juga diukur dengan melihat adanya kecendrungan negara-negara kawasan Asia Tenggara yang sebelumnya tidak berkepentingan atau memiliki urgensi dalam memerangi penyelundupan manusia yang sama dengan Australia untuk ikut bergabung. Bali Process beranggotakan 48 negara dan 3 organisasi internasional yaitu IOM, UNHCR dan UNODC (United Nations Office of Drug Crime). Bali Process menjadi langkah awal Australia membawa isu terkait IMA ke level regional sekaligus memperkuat kerjasama dengan Indonesia. Ada lima poin dari pertemuan Bali Process yaitu, (1) meningkatkan kerjasama antar pihak penegak hukum negara-negara anggota; (2) membangun informasi secara efektif dan pertukaran data intelijen; (3) meningkatkan penerapan upaya perlindungan, efektifitas pengembalian korban, dan bantuan bagi korban; (4) meningkatkan kerjasama dalam sistem visa serta perbatasan dalam mendekteksi dan mencegah migrasi illegal; dan (5) meningkatkan perhatian terhadap usaha untuk mengatasi akar permasalahan.

Dalam kerangka kerjasama bilateral, komitmen Australia dan Indonesia semakin dipererat dengan penandatanganan Lombok. Treaty pada 
tahun 2006. Lombok Treaty adalah kerjasama bidang keamanan yang lebih spesifik menekankan pada kebijakan terkait pertahanan, kontra terorisme, kerjasama intelijen, keselamatan dan keamanan penerbangan, keamanan maritim, tanggap darurat bencana alam, pencegahan senjata pemusnah massal, serta peningkatan pemahaman antara masyarakat kedua negara (Perwita, 2008). Melalui AustraliaIndonesia Agreement on the Framework. for Security Cooperation Treaty atau perjanjian Lombok yang diratifikasi pada tahun 2007, Australia memberikan dana $\$ 50$ juta yang digunakan bagi penguatan kemampuan Indonesia untuk menangani illegal migrant, dan $\$ 3,6$ juta untuk upaya mencegat para pencari suaka yang berada di wilayah laut Indonesia agar mereka tidak masuk ke wilayah laut Australia (Sofyan, 2017). Hal yang perlu dicermati terkait perjanjian ini adalah posisi Indonesia dan Australia yang tidak seimbang dari sisi kesiapan dan kemampuan militer yang dimiliki. Bidang kerjasama yang tercantum dalam perjanjian tersebut selaras dan memihak kepada kepentingan Australia yang tertuang pada dokumen The Defence 2000 White Paper dan Defence Update 2007 (Rizka \& Prabaningtyas, 2015).

Australia dan Indonesia juga menyepakati Management and Care of Irregular Immigrant Project (MCIIP) pada tahun 2007 yang salah satu kepentingan utamanya adalah melakukan renovasi atau perbaikan rumah detensi bagi migran yang sesuai dengan standar (Nethery, RaffertyBrown, \& Taylor, 2012). Segala bentuk kerjasama dengan Indonesia ini menunjukkan keseriusan Australia dalam menangani ancaman dari isu IMA. Tidak hanya dengan Indonesia, Australia juga menjalin kerjasama dengan Malaysia dalam menangani isu IMA. Malaysia adalah mitra kawasan utama di Bali Procces dan kerjasama ini merupakan langkah yang sangat penting dalam kerangka kerjasama kawasan. Selain itu sama seperti Indonesia, Malaysia juga merupakan negara transit pengungsi dan pencari suaka yang menuju Australia. Kerjasama antara Australia dan Malaysia dikenal dengan istilah people swap yang ditandatangani oleh Australia pada tanggal 25 Juli 2011 dan memuat terkait persetujuan kedua negara untuk melakukan transfer serta pemindahan pencari suaka antara kedua negara. Kesepakatan ini memuat kewajiban Australia untuk memindahkan 800 pencari suaka illegal ke Malaysia untuk ditangani oleh UNHCR. Sebaliknya sebagai penganti dari kebijakan Australia ini, Malaysia akan mengirimkan 4.000 imigran yang berstatus resmi ke Australia (McKenzie \& Hasmath, 2013). 
Salah satu upaya Australia dalam membawa isu IMA ke tingkat regional adalah kerjasama dengan negaranegara di Asia Pasifik melalui kebijakan Pacific Solution (Solusi Pasifik). Berawal dari peristiwa Tampa atau disebut Tampa Affair. Pada tanggal 26 Agustus 2001, sebuah kapal muatan yang bernama MV Tampa yang berlayar dari Norwegia menuju Singapura diminta bantuan oleh Australia untuk menyelamatkan sebuah kapal nelayan dari Indonesia yang hampir tenggelam. Kapal tersebut bernama Palapa dan membawa penumpang yang mayoritas adalah pengungsi dan pencari suaka yang berjumlah 433 orang. Mereka berada di laut internasional antara Australia dan Indonesia dan berjarak 140 kilometer dari Pulau Christmas. Kapal MV Tampa berhasil menyelamatkan para penumpang dan berniat membawa mereka kembali ke Indonesia, namun para penumpang tersebut mengancam bunuh diri apabila tidak diantar ke Australia. Pengungsi ini illegal dan dibantu para penyelundup Indonesia sehingga dilarang untuk memasuki wilayah Australia. MV Tampa akhirnya berbalik arah dan menuju Pulau Christmas yang termasuk wilayah Australia yang dekat dengan Indonesia, namun sebelum memasuki wilayah Australia MV Tampa diperintah kembali menuju Indonesia oleh Pemerintah Australia. Akhirnya Kapten kapal memutuskan untuk berada di luar wilayah perairan Australia dan menunggu. Keesokan harinya, kapal MV Tampa kembali meminta izin pemerintah Australia untuk masuk dengan pertimbangan kapal tersebut hanya didesain dengan kapasitas 50 kru dan kelebihan muatan karena menampung pengungsi dan pencari suaka yang diselamatkan. Selain itu banyak dari mereka yang butuh pertolongan medis akibat peristiwa tersebut. Namun permintaan ini masih saja ditolak oleh pemerintah Australia sehingga MV Tampa tetap memaksa masuk wilayah perairan Australia. Australia akhirnya mengirimkan 45 anggota SAS (Special Air Sevices Forces) untuk mencegah dan menghentikan kapal tersebut. Penumpang yang membutuhkan bantuan medis dipindahkan ke kapal militer untuk perawatan sedangkan sisanya 131 orang dibawa ke Selandia Baru dan sebanyak 302 orang di kirim ke Pulau Nauru (McAdam \& Purcell, 2008).

Akibat dari peristiwa Tampa Affair, Perdana Menteri John Howard menandatangani berbagai kerjasama untuk menangani imigran illegal dengan negara Papua Nugini dan Nauru terkait pembukaan pusat detensi (offshore processing) pada kedua negara tersebut. Perjanjian yang dicapai antara Australia, Nauru dan 
Papua Nugini adalah hasil dari serangkaian negosiasi dengan negaranegara di Asia Pasifik yang dilakukan dalam upaya untuk memastikan bahwa kapal yang tidak sah tidak dibawa ke Australia untuk diproses. Kebijakan terkait kerjasama ini mulai diterapkan dari bulan September 2001. Melalui kebijakan ini, angkatan laut Australia berpatroli sepanjang batas luar wilayah laut Australia dengan menggunakan kapal yang berkecepatan tinggi dan bertujuan mencegah setiap perahu atau kapal berpenumpang pengungsi dan pencari suaka yang hendak masuk ke wilayahnya.

Pacific Solution terdiri dari 3 (tiga) strategi utama yaitu: (1) menghapus ribuan pulau dari zona migrasi atau wilayah Australia; (2) Operasi Relex Angkatan Pertahanan Australia untuk mencegat kapal-kapal yang membawa pencari suaka; dan (3) pencari suaka dipindahkan ke pusat penahanan di Nauru dan Papua Nugini untuk penentuan status pengungsi. Kebijakan Pacific Solution dianggap kontroversial sehingga menuai banyak kecaman dari dunia internasional. Kebijakan ini dapat mengembalikan para pengungsi pada kondisi ketakutan karena ancaman yang dialami dan melanggar prinsip non-refoulement yang tertera dalam Konvensi 1951.

Upaya-upaya kerjasama yang dilakukan Australia dengan beberapa negara transit tersebut menunjukkan bahwa Australia telah membawa isu IMA dalam tata kelola pengungsi secara bilateral maupun regional. Australia berusaha memastikan adanya kerangka hukum yang jelas terkait dengan penanganan IMA. Tentunya bentuk kerjasama Australia ini menuai banyak pro dan kontra, namun secara umum Australia menunjukkan keberhasilannya dalam memasukan kepentingan keamanan nasionalnya menjadi kepentingan negara lain seperti Indonesia, Malaysia dan negara-negara di Asia Pasifik.

\section{Kritik Internasional terhadap Kebijakan Penanganan IMA di Pulau Manus dan Nauru}

Kerjasama Pacific Solution menghasilkan adanya pusat penahanan pengungsi dan pencari suaka yang berada di Pulau Manus dan Nauru. Tidak banyak yang dapat diketahui terkait keadaan rumah detensi Australia di kedua pulau tersebut, karena Australia sering mengabaikan permintaan informasi atau akses ke dalamnya. Namun dari pengakuan para pengungsi dan hasil kunjungan Tim UNHCR ke rumah detensi tersebut, disampaikan bahwa keadaan rumah detensi di Pulau Manus dan Nauru sangat memprihatinkan. Kedua pulau ini diisi dengan ribuan para pencari suaka yang hidup di tendatenda pengungsian yang penuh sesak, tidak higiensi, panas dan sulit 
berkembang, rusuh serta kesulitan air bersih. Hal ini menyebabkan banyak pengungsi tertular penyakit, melakukan mogok makan dan mengalami gangguan jiwa hinga kematian (Ernawati, 2019). Kematian tersebut diakibatkan pengungsi terkena penyakit maupun melakukan bunuh diri.

Kebijakan Australia terkait rumah penahanan pengungsi dan pencari suaka ini menuai berbagai respon dan kritikan dari dunia internasional. Salah satunya adalah dari Komisioner Tinggi PBB untuk Hak Asasi Manusia (HAM) Michelle Bachelet yang prihatin terhadap migrasi dan kebijakan suaka di Australia. Dalam pidatonya dalam sebuah acara orasi Whitlam Institute di Sydney, Barchelet mengatakan kekhawatiran mengenai penanganan pengungsi yang dilakukan di luar Australia dan penahanan yang berkepanjangan terhadap para pengungsi dan pencari suaka. Selain itu, ia mendesak adanya belas kasihan dan rasa kemanusiaan dari pihak yang berwenang mengelola tempat tersebut. Keprihatinan ini didasari oleh keputusasaan yang ditunjukkan oleh pengungsi dan pencari suaka yang mencari keselamatan dan martabat mereka. Mereka harus dilihat bukan sebagai penjahat melainkan korban. Mereka memilih mengungsi karena terpaksa dan tidak memiliki pilihan lain. Komisioner Tinggi PBB ini menyayangkan sikap Australia sebagai negara pihak dalam Konvensi Pengungsi 1951 yang telah keluar dari diskusi global yang sangat penting untuk memperoleh solusi kooperatif terkait pengungsi dan pencari suaka (Liputan 6, 2019). Kritik juga datang dari organisasi pengungsi internasional yaitu UNHCR terkait standar prosedur perlindungan para pencari suaka. Kebijakan yang diambil Australia dengan langsung mengirim para pengungsi dan pencari suaka yang datang ke Australia menggunakan jalur laut ke Pulau Manus dan Nauru, serta untuk menjadikan kedua pulau tersebut sebagai lokasi klaim suaka menjadi pengungsi dianggap kurang sesuai. Komisioner PBB untuk Pengungsi tersebut menyatakan secara signifikan ada kekurangan dan kelemahan pada sistem hukum Papua Nugini terkait proses status pencari suaka tersebut. Menurut UNHCR Papua Nugini saat ini tidak siap dalam memproses pencari suaka tersebut, disebabkan tidak adanya keahlian dan kapasitas terkait pengelolaannya (BBC News, 2013).

Terakhir muncul kritik dari Indonesia sebagai negara tetangga yang berbatasan langsung dengan Australia dan menjadi negara transit bagi pengungsi dan pencari suaka tersebut. Kritik ini disampaikan oleh Lembaga Swadaya Masyarakat (LSM) yang bernama SUAKA. SUAKA berisi 
Yayasan Lembaga Bantuan Hukum Indonesia, Lembaga Bantuan Hukum Jakarta, dan Human Rights Working Group. Mereka mengkritik bahwa keputusan yang diambil oleh Australia tidak sejalan dengan prinsip perlindungan HAM dan ketentuan yang tertera dalam Konvensi 1951. Melalui juru bicaranya, Ali Akbar Tanjung mengatakan kepada Radio Australia bahwa yang telah dilakukan oleh Pemerintah Australia bukanlah menunjukkan sebuah keberhasilan tetapi merupakan pelanggaran terhadap hak-hak asasi para pengungsi. Australia seharusnya bekerjasama dengan Indonesia dan negara lain untuk mendorong pihak keamanan segera bertindak terhadap penyelundupan manusia yang mengambil keuntungan dari kondisi yang dialami oleh pengungsi dan pencari suaka sehingga bukan malah menakuti mereka dengan menempatkannya di Nauru maupun Papua Nugini. Kebijakan Australia ini bersifat diskriminasi karena hanya dikenakan bagi pencari suaka yang datang melalu jalur laut saja. Hal ini sudah pasti melanggar mandat internasional yang dijalankan oleh Australia. SUAKA berharap pemerintah Australia mau melakukan revisi terhadap kesepakatan tersebut, terutama yang terkait batas waktu bagi pencari suaka yang tinggal di Pulau Manus dan Nauru untuk segera memperoleh status sebagai pengungsi (Republika, 2013).

\section{KESIMPULAN}

Australia sebagai salah satu negara yang meratifikasi Konvensi Pengungsi 1951, berkewajiban menerapkan prinsip non-refoulement terkait tata kelola global penanganan pengungsi dan pencari suaka. Namun hal tersebut bertolak belakang dengan penanangan isu IMA. Lonjakan arus kedatangan IMA ke Australia menyebabkan Australia mulai menerapkan kebijakan yang restriktif dan terbatas dalam penanganannya. Australia melihat IMA tidak berbeda dengan pelaku kriminal terkait smuggling dan trafficking yang menjadi ancaman bagi kedaulatan wilayahnya. Kebijakan sekuritisasi migrasi yang memandang IMA berbahaya dan illegal, mengabaikan kenyataan bahwa IMA sebenarnya adalah mereka yang membutuhkan perlindungan dan pertolongan dunia internasional. Dalam tata kelola penanganan IMA secara global, Australia berhasil melakukan kerjasama dengan negaranegara transit pengungsi seperti Indonesia, Malaysia dan negara-negara di Asia Pasifik. Kerjasama tersebut menunjukkan bahwa Australia berhasil membawa kepentingan nasionalnya menjadi kepentingan negara lain bahkan menjadi kepentingan di tingkat regional. Negara-negara yang 
bekerjasama dengan Australia dikonstruksi untuk memandang IMA sebagai ancaman terhadap pengungsi dan pencari suaka secara global. Salah satu kebijakan Australia terkait pembukaan tempat penahanan para pencari suaka yang berada di pulau Manus dan Nauru mendapat kritik tajam dari dunia internasional. Australia dituntut untuk mempertimbangkan kembali semua kebijakan yang dimaksud.

Implementasi dari kebijakan Australia dalam menangani IMA dapat menjadi bukti adanya tantangan dalam rezim internasional terkait pengungsi dan pencari suaka. Tantangan yang dimaksud adalah dimana negaranegara pihak yang menandatangani Konvensi 1951 mulai mengalami dilema terkait penerapan prinsip nonrefoulement dan perlindungan terhadap kepentingan nasional negaranya. Pengungsi dan pencari suaka yang datang ke negaranya dapat menjadi ancaman terhadap keamanan manusia maupun wilayah negaranya. Terkait dengan keamanan manusia terdiri dari 7 (tujuh) aspek yaitu keamanan ekonomi, keamanan pangan, keamanan kesehatan, keamanan lingkungan, keamanan individu, keamanan komunitas dan keamanan politik. Sedangkan terkait dengan keamanan wilayahnya, kebijakan sekuritisasi migrasi diberlakukan untuk mencegah adanya penyelundupan atau perdagangan orang ataupun ancaman terorisme. Selain itu, pendefinisian pengungsi yang belum jelas menyebabkan sebagian besar negara menggunakan penilaian masingmasing dalam menerapkan interpretasi yang lebih luas dari kriteria yang ditentukan dalam implementasi konvensi pengungsi tersebut.

\section{REFERENSI}

Akbar, R. (2015) Dampak Kebijakan Australia Terkait Isu Pencari Suaka Terbadap Hubungan Bilateral Australia-Indonesia (2013-2015).

Alunaza, H., Maulana, I., \& Sudagung, A. D. (2018) "The Pacific Solution as Australia Policy towards Asylum Seeker and Irregular Maritime Arrivals (IMAs) in John Howard Era", Jurnal Ilmiah Hubungan Internasional, 14(1), 61. https://doi.org/10.26593/jihi.v14i1.2 789.61-75

BBC News. (2013) UNHCR kritik Australia menangani pencari suaka (Online).

Tersedia di:

https://www.bbc.com/indonesia/dun ia/2013/07/130726_unhcr_kritik_aus tralia (Diakses: 22 December 2019).

Cadwallader, R. (2015) We Are Better Than This: Essays and Poems on Australian Asylum Seeker Policy. Australia: ATF Press Adelaide.

Ernawati, N. (2019) "Konsekuensi Hukum Penerapan Dua Kebijakan Australia selaku Anggota Konvensi Pengungsi Tahun 1951 di Tinjau dari Kovensi Wina 1969". Jurnal IUS, 7(1).

Evans, G. (2004) Foreign Policy and Good International Citizenship. (March 1990), $1-8$.

Khoser, K. O. and G. G. (2014) Refugees And Migration. In T. G. Weiss \& R. 
Wilkinson (Eds.), International Organization and Global Governance. https://doi.org/10.1146/annurev.bio chem.72.121801.161724

Liputan 6. (2019) PBB Kritik Kebijakan Australia terhadap Pengungsi dan Pencari Suaka - Global Liputan6.com (Online). Tersedia di: https://www.liputan6.com/global/re ad/4082878/pbb-kritik-kebijakanaustralia-terhadap-pengungsi-danpencari-suaka (Diakses: 22 December 22).

Marisa, N. L. M. A. (2018) Dilema Pemerintah Australia dalam Implementasi Prinsip Good International Citizenship pada Kebijakan terkait Pengungsi dan Pencari Suaka Pada Masa Pemerintahan Tony Abbott dan Malcolm Turnbull. Departemen Imu Hubungan Internasional FISIPOL UGM. https://doi.org/10.1017/CBO978110 7415324.004

McAdam, J., \& Purcell, K. (2008) Refugee Protection in the Howard Years: Obstructing the Right to Seek Asylum. Australian Year Book of International Law, Vol. 27.

McDonald, M. (2005) Constructing insecurity: Australian security discourse and policy post-2001. International Relations, 3, 297-320.

McKenzie, J., \& Hasmath, R. (2013) Deterring the 'boat people': Explaining The Australian Government's People Swap Response to Asylum Seekers. Australian Journal of Political Science.

Millar, C. (2004) “Bali Process"-Building Regional Cooperation to Combat People Smuggling and Trafficking in Persons.Millar, C. (2004). "Bali Process"-Building Regional Cooperation to Combat People Smuggling and Trafficking in Persons. Speech by the Australian Ambassador f. Speech by the Australian Ambassador for
People Smuggling Issues, Institute for the Study of Global Movements, Monash University, Melbourne, 29.

Nethery, A., Rafferty-Brown, B., \& Taylor, S. (2012) Exporting Detention: Australiafunded Immigration Detention in Indonesia. 26(1). https://doi.org/10.1093/jrs/fes027

Nurcahyawan, T., \& Andika, S. R. (2017) Permintaan Maaf Australia dan Prinsip Non Refoulement (Studi Kasus Pencari Suaka Sri Lanka). Jurnal Era Hukum, 2(1).

Perwita, A. A. B. P. (2008) "Signifikansi Perjanjian Lombok bagi Hubungan Indonesia dan Australia", Satria Studi Pertahanan, 4, No. 4.

Phillips, J. (2014) Boat arrivals in Australia: a quick guide to the statistics. Parliament of Australia.

Phillips, J., \& Spinks. (2013) Boat arrivals in Australia since 1976. Parliament of Australia.

Republika. (2013) LSM Indonesia Kritik Kebijakan Australia Soal Pencari Suaka (Online). Tersedia di: https://www.republika.co.id/berita/i nternasional/abc-australianetwork/13/08/17/mrn494-lsmindonesia-kritik-kebijakan-australiasoal-pencari-suaka (Diakses: 22 Desember 2019).

Rizal, F. (2019) "Kebijakan Unilateral Penanganan Imigran Ilegal Australia Pasca Pemilihan Umum Australia Tahun 2013", Global: Jurnal Politik Internasional, 20(2), 137. https://doi.org/10.7454/global.v20i2. 332

Rizka, R. A., \& Prabaningtyas, F. (2015) Dampak Kebijakan Illegal Maritime Arrivals (IMA) Australia terhadap Hubungan Australia-Indonesia Kontemporer. 69-81.

Saraswati, D. A. (2019) "Sekuritas Migrasi Australia pada Masa Kepemimpinan 
Perdana Menteri Malcom Turnbull", Jurnal of International Relations Undip, 5, Nomor 3(1), 544-553.

https://doi.org/.1037//0033-

2909.I26.1.78

Sofyan, B. (2017) Menyikapi Arus Imigran

Gelap Menuju Australia guna

Mengamankan Kepentingan Nasional Indonesia dalam Rangka Ketahanan

Nasional. (February).

Ulfah, N. (2019) "Perlindungan Keamanan

Manusia Australia Melalui Kebijakan

Turn Back The Boat Pada Masa

Pemerintahan Tony Abbot", Journal of

International Relations Undip, 677, 671677.
UNHCR. (1951) Konvensi dan Protokol mengenai Status Pengungsi (Online).

Tersedia di:

https://www.unhcr.org/id/wpcontent/uploads/sites/42/2017/05/

KonfensidanProtokol.pdf

Wuryandari, G. (2010). Menelaah Politik Luar Negeri Indonesia dalam Menyikapi Isu Perdangangan Manusia. Ejournal Politik LIPI. 